\title{
Studies on the Dyeing Of Wool and Nylon Fabrics with Some Acid Dyes
}

\author{
Haruna Musa* ${ }^{1}$, Abdulmumini ${ }^{1}$., Folashade M. $\mathrm{O}^{1}$., Bishir Usman ${ }^{1}$ and \\ Hamza $\mathrm{Abba}^{2}$ \\ ${ }^{1}$ Department of Pure and Industrial Chemistry, Bayero University, P.M.B. 3011, Kano, Nigeria. \\ ${ }^{2}$ Department of Chemistry, Ahmadu Bello University, Zaria, Nigeria.
}

\begin{abstract}
Wool and nylon fabrics were dyed using four different types of acid dyes of various colours i.e Lugani 101 (black), brown 3RG, nylomine (navy blue), methyl orange. Generally both wool and nylon fabrics exhibited higher percentage exhaustion. Relatively, nylon showed higher percentage exhaustion compared to wool. Also the dyed wool and nylon fabrics possess good fastness towards bleaching rubbing, pressing and perspiration but poor fastness to higher and washing.
\end{abstract}

Keywords - Acid dyes, exhaustion, fastness, nylon, wool,

\section{INTRODUCTION}

Acid dyes are primary organic acids, usually available to the dyer in the form of salts. They are generally applied to fibre from solutions containing sulphuric, formic or acetic acids. However, majority of them are sodium salts of aromatic suphonic acids $\left(\mathrm{RSO}_{3} \mathrm{~N} a\right.$ ) but there are a few containing carboxylic groups. Most acid dyestuffs acquire their acidity from the present of sulphonic acid groups $\left(-\mathrm{SO}_{3}\right)$ or nitro $\left(-\mathrm{NO}_{2}\right)$ groups in the molecule [1]. Acid dyes being water-soluble anionic dyes are applied primarily to nitrogenous fibers such as wool, silk and nylon, all of which contain basic groups. They provide a complete colour range, varying from yellow to back, many of the being very bright [2].

Wool is the protein fibers obtained from the fibrous covering of sheep. Among the fibres used through ages to clothe man, wool occupies a unique position. However to provide the finest quality wool for the present day consumer, production is carefully and scientifically controlled. The finest quality wool is obtained from the merino, a breed that originated in Spain. The animal is small bodied, with many long, loose folds of skin. The fibre is fine and of high quality [3].

The coined word "nylon" is now an acceptable generic term for a group of synthetic polyamide fibres. The nylon fibres are long chain polymers with recurring amide (-CONH-) groups as an integral part of the main chain and so exhibits somewhat similar properties to proteins which are long chain polypeptides [4]. The nylons owe their existence to the genius of Wallace Carothers, research chemist heading a program of polymer research initiated by E. I Dupont de Nemours and Co in 1928. The research led to the introduction of the first commercial nylon, designated nylon 6.6 based on the number of carbon atoms in each of the reacting monomer [4].

Moreover, various reports are available in the literature on dyeing of wool and nylon with acid dyes the reason being that, acid dyes are used on fibres with cationic sites [5]. Though both wool and nylon can be dyed with reactive dyes, selected direct dyes and metal complex dyes, the present study intends to study the dyeing of wool and nylon fabrics with some acid dyes (Lugani 101 Brown 3RG, nylonmine and methylorange) with a view to assess and compare the fastness properties of the dyed fabrics towards various agencies which may likely provide an idea for a more compatible dye to be use for dyeing wool and nylon fabrics for economical dyeing as well as anticipated fastness properties that may be required by both local and commercial dyers [6].

\section{Material and Methods}

All glasswares used were well washed with a detergent, rinsed with distilled water and dried in an over before use. Weighing was carried out on digital balance model, AB54 to four decimal places. Chemicals of analytical grade purity were used. The four different acid dyes were kindly supplied by African Textile Mills in Kano State, Nigeria and are of higher purity. Fastness properties as well as absorbance measurements were performed in African Textile Mills laboratory using standard equipments.

\subsection{Scouring}

$3.5 \mathrm{~g}$ of the fabrics wet with distilled water and soaked in a bath containing $0.8 \%$ Wanklin soap solution using liquor ratio 30:1. The mixture was heated to boil with continuous stirring for 1 hour at a temperature of $60^{\circ} \mathrm{C}$. The fabrics were then rinsed with water and allowed to dry $[7,8]$. 


\subsection{Bleaching}

$1 \mathrm{~g}$ of wool fabric was immersed in a solution containing $10 \mathrm{~cm}^{3}$ of $30 \%$ hydrogen peroxide $\left(\mathrm{H}_{2} \mathrm{O}_{2}\right)$, $6 \mathrm{~cm}^{3}$ of $10 \% \mathrm{mgSO}_{4}$ and $100 \mathrm{~cm}^{3}$ of water. The fabric was then rinsed with water and allowed to dry [8].

\subsection{Determination of $\lambda \max$}

$0.01 \mathrm{~g}$ each the four dyes was dissolved separately in 1 litre of distilled water. The absorbance of the dye solutions was then measured at varying wavelengths between $400-700 \mathrm{~nm}$ at an interval of $10 \mathrm{~nm}$.

\subsection{Calibration curve}

The calibration curve for each dye was obtained by taking the absorbance at different concentrations of the dye solutions at their respective $\lambda$ max. The range of concentrations used were $0.01 \mathrm{~g} / \mathrm{litre}, 0.005 \mathrm{~g} / \mathrm{litre}$, $0.0033 \mathrm{~g} / \mathrm{litre}, \quad 0.0025 \mathrm{glitre}, \quad 0.00166 \mathrm{~g} / \mathrm{litre}, 0.00143 \mathrm{~g} / \mathrm{litre}, \quad 0.00125 \mathrm{~g} / \mathrm{litre}, 0.00111 \mathrm{~g} / \mathrm{litre}$ and $0.01 \mathrm{~g} / \mathrm{litre}$. Absorbance was then plotted against concentration (g/litre).

\subsection{Dyeing of wool}

The recipe used were: $3.5 \mathrm{~g}$ fabric, liquor ratio $(100: 1)$ volume of dye $\left(50 \mathrm{~cm}^{3}\right)$ and volume of Glaubers salt $\left(15 \mathrm{~cm}^{3}\right)$. The concentrations of the stock solutions used were: Dye solution $1 \%$, Glaubers salt $10 \%$ and $\mathrm{H}_{2} \mathrm{SO}_{4} 99 \%$. Simple laboratory methods of dyeing were adopted in dyeing the wool fabric with acid dyes as follows: $3.5 \mathrm{~g}$ of wool fabric was immersed in the dye bath containing the above recipe and was stirred for 15 miutes. The dye bath was heated to $90^{\circ} \mathrm{C}$ for over 30 minutes with $10 \mathrm{~cm}^{3}$ of the sodium sulphate added after 15 minutes, the remaining $5 \mathrm{~cm}^{3}$ was added at $90^{\circ} \mathrm{C}$. The temperature was maintained for another 60 minutes with stirring $[2,9]$.

\subsection{Dyeing of Nylon}

The recipe used were: $3.5 \mathrm{~g}$ fabric, liquor ratio $(100: 1)$ volume of dye $\left(50 \mathrm{~cm}^{3}\right)$, volume of hexamethylenediammine $\left(10 \mathrm{~cm}^{3}\right)$ and volume of ammonium acetate $\left(10 \mathrm{~cm}^{3}\right)$. The concentrations of the stock solution used were: $1 \%$ Dye solution, $3 \%$ ammonium acetate and $1 \%$ hexamethylene diammine. $10 \mathrm{~cm}^{3}$ of hexamethylene diammine and $10 \mathrm{~cm}^{3}$ of ammonium acetate were mixed and $\mathrm{pH}$ raised to 6.5 and the temperature was also gradually raised to $98^{\circ} \mathrm{C} .50 \mathrm{~cm}^{3}$ of $1 \%$ dye solution was then added to the dye bath. The fabric was then immersed in the dye solution and dyeing was carried out for 45 minutes. The fabric was then removed, rinsed and allowed to dry $[2,10]$.

\subsection{Soaping}

$3.5 \mathrm{~g}$ of the dyed wool fabric was immersed in $25 \mathrm{~cm}^{3}$ of $2 \mathrm{~g} /$ litre detergent solution and stirred continuously for 30 minutes at room temperature. The fabric was then removed, rinsed and allowed to dry.

\subsection{Fastness to washing}

\section{Colour Fastness Tests}

The dyed specimens of dimension $5 \mathrm{~cm} \mathrm{X} 4 \mathrm{~cm}$ each were placed between two pieces of undyed cotton fabric of the same dimension. The three pieces attached to each were held together by stitching round the edges to make a composite specimen. The specimen was placed in the wash liquor containing $25 \mathrm{~cm}^{3}$ of $2 \mathrm{~g} / \mathrm{litre}$ detergent solution, heated for 30 minutes at $60^{\circ} \mathrm{C}$. The composite specimen were then removed, thoroughly rinsed, opened and air-dried. The change in colour and the staining of the adjacent undyed fabric were assessed using the grey scale [11].

\subsection{Fastness to bleaching}

The dyed wool and nylon fabrics were cut into $5 \mathrm{~cm} \mathrm{X} 4 \mathrm{~cm}$ pieces, placed between two pieces of undyed white fabric and stitched together round the edges to make a composite specimen. Each of the specimen was treated with $25 \mathrm{~cm}^{3}$ of $30 \%$ hydrogen peroxide. They were then removed, rinsed and air dried. The dyed fabric was detached from the undyed one. The change in colour and degree of staining of the undyed material were assessed using the appropriate grey scale[12].

\subsection{Fastness to dry pressing}

This was carried out by positioning $5 \mathrm{~cm} \mathrm{X} 4 \mathrm{~cm}$ dyed fabric on a piece of dried white cloth of the same size and then pressed with a hot pressing iron for 20 seconds. The change in colour of the dyed material and the degree of staining of the undyed cloth were assessed using grey scale 


\subsection{Fastness to damp pressing}

The damp pressing was carried out by placing the dyed fabric $(5 \mathrm{~cm} \mathrm{X} 4 \mathrm{~cm})$ between the dried white cloth and a wet white cloth of the same size. The wet white cloth was placed on top white the dried white cloth was placed below. They were then pressed together for 20 seconds. The change in colour of the dyed material and the degree of staining of the white cloth were assessed using grey scale.

\subsection{Fastness to rubbing}

The dyed fabrics in contact with undyed fabric were pinned together (size, $5 \mathrm{~cm} \mathrm{X} 4 \mathrm{~cm}$ ). The two were rubbed several times together by hand. The change in colour and degree of staining of the undyed fabric was assessed using the appropriate grey scale.

\subsection{Fastness to light}

Strips of the dyed fabric and the blue wool standard were cut and mounted on a cardboard paper and half portions of the specimens were covered to block the source of light from getting to that portion. The specimens were exposed to artificial light source in a fadeometer instrument for two weeks. Eight Blue Wool Standards were also exposed simultaneously with the specimens for the same period. The specimens were then removed and the extents of their fading were assessed in comparison with the blue wool standard.

\subsection{Fastness to perspiration}

The perspiration fastness test required two different solutions i.e the acidic and the alkaline perspiration solutions. The test was carried out using composite specimen which was prepared as described previously. The composite specimens were immersed separately in alkaline and acidic solutions using liquor ratio of 20:1. The specimens were left in the solutions for 30 minutes at room temperature after which the specimens were brought out, drained and placed in between two glass slides for four hours. They were then removed and dried. The colour change of the dyed fabrics and degree of staining of the adjacent white fabrics were assessed using a grey scale.

\section{V Results And Discussions}

4.1 Purification of fabrics, Determination of $\lambda \max$ and Preparation of Calibration Curve

Scouring and bleaching are performed on fabrics before dyeing in order to remove natural fats, waxes, proteins, dirt, oil, impurities and colouring matter. The scored fabric was found to be cleaner with higher rates of dye absorption and equally, the bleached fabric (wool) becomes white while the appearance of nylon fabric after bleaching remains the same as it were before bleaching i.e there was no visible change after bleaching of the nylon fabrics. This result suggest that wool being a natural fibre contains natural colouring matters or impurities which can only be removed by bleaching in contrast to nylon which is man - made fibre, devoid of coloured impurities hence can be dyed without further purification.

The $\lambda \max$ of the four dyes are presented in Table 1.

Table 1: $\lambda \max$ values for dye A, B, C, and D

\begin{tabular}{ccc}
\hline Dye & Name of dye & \multicolumn{1}{c}{ max $(\mathbf{n m})$} \\
\hline A & Lugani 101 & $600 \mathrm{~nm}$ \\
B & Methyl orange & $501 \mathrm{~nm}$ \\
C & Brown 3RG & $440 \mathrm{~nm}$ \\
D & Nylomine & $400 \mathrm{~nm}$ \\
\hline
\end{tabular}

The $\lambda$ max values obtained for the four dyes varied from $600 \mathrm{~nm}$ for dye A to $400 \mathrm{~nm}$ for dye D. the difference in the $\lambda \max$ values for the dyes may be due to the fact that the dyes have different colours and different chromophore constitution; hence they will absorb radiation selectively from the visible region (4).

Similarly, the absorbance values of different concentrations of dyes A, B, C and D at various $\lambda$ max are presented in Table 2. 
Table 2: Absorbance value at different concentrations of dye A, B, C, and D at their various $\lambda$ max

\begin{tabular}{ccccc}
\hline & \multicolumn{4}{c}{ Absorbances } \\
Concentration of dyes $(\mathbf{g} / \mathbf{L})$ & Dye A & Dye B & Dye C & Dye D \\
\hline 0.01 & 1.268 & 1.82 & 0.843 & 0.018 \\
0.005 & 0.683 & 1.644 & 0.451 & 0.018 \\
0.0033 & 0.440 & 1.361 & 0.317 & 0.016 \\
0.0025 & 0.322 & 1.034 & 0.234 & 0.014 \\
0.002 & 0.262 & 0.859 & 0.180 & 0.012 \\
0.0016 & 0218 & 0.729 & 0.150 & 0.011 \\
0.00143 & 0.179 & 0.670 & 0.128 & 0.010 \\
0.00125 & 0.161 & 0.565 & 0.113 & 0.009 \\
0.00111 & 0.136 & 0.470 & 0.100 & 0.006 \\
0.001 & 0.122 & 0.355 & 0.09 & 0.005 \\
\hline
\end{tabular}

\subsection{Dyeing}

At the end of the dyeing process, using the exhaustion method for the two fabrics, dyed fabrics of different depth of shades were obtained with wool fabric having higher depth of shades as evident from visual assessment of the dyed materials.

\subsection{Percentage exhaustion $(\% \mathrm{E})$}

This is the amount of dye uptake by the fabric was calculated using the equation:

$$
\% \mathrm{E}=\frac{\mathrm{C}_{\mathrm{i}}-\mathrm{C}_{\mathrm{f}}}{\mathrm{C}_{\mathrm{i}}} \times 100
$$

Where $\mathrm{C}_{\mathrm{i}}=$ concentration of the dye in the dyebath before dyeing

$\mathrm{C}_{\mathrm{f}}=$ concentration of dye in the dyebath after dyeing.

The results for percentage exhaustion of dyes on wool and nylon are presented in table 3 and 4 respectively.

Table 3: Percentage exhaustion $(\% \mathrm{E})$ of dyes on wool

\begin{tabular}{cccc}
\hline Dye & $\mathbf{C}_{\mathbf{i}}$ & $\mathbf{C}_{\mathbf{f}}$ & $\boldsymbol{\%} \mathbf{E}$ \\
\hline $\mathrm{A}$ & 0.01 & 0.0027 & $73 \%$ \\
$\mathrm{~B}$ & 0.01 & 0.006 & $94 \%$ \\
$\mathrm{C}$ & 0.01 & 0.0022 & $78 \%$ \\
$\mathrm{D}$ & 0.01 & 0.0038 & $62 \%$ \\
\hline
\end{tabular}

The percentage exhaustion of dyes varies from $89 \%$ to $50 \%$ for wool and $62 \%$ to $94 \%$ for nylon fabrics. Dye B has the highest percentage exhaustion for both wool and nylon (i.e 89\% for wool and $94 \%$ for nylon). This may be due to its relatively low molecular size and also low anion affinity which enable it to exhibit good leveling and migration properties.

Generally it can be seen from the tales (3 and 4) that acid dyes exhibit higher affinity on nylon and wool. The substantivity for acid dyes derives mainly from the presence in their structure of terminal amino groups, and to some extent also, of amide links in the polymer chain. The higher parentage exhaustion of these dyes may be due to the presence of large number of amino end groups (AEG) on nylon fibre.

However, the mechanisms of dyeing nylon and wool with acid dyes are shown in figure 1 and 2. From figure 1 , it can be seen that dye attachment onto nylon is by ionic or salt links.

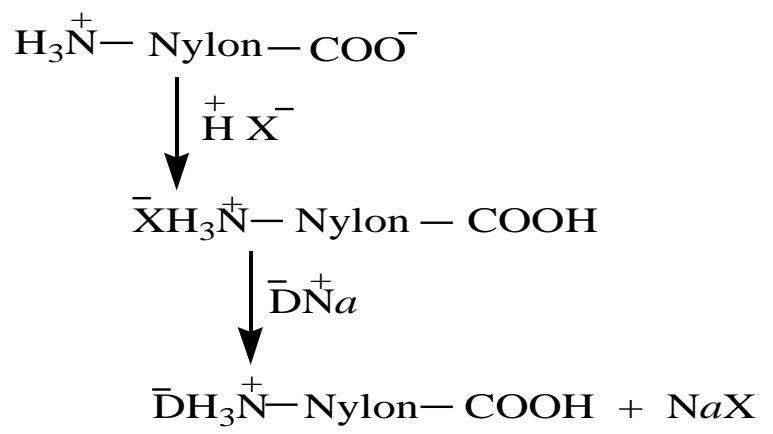

Figure 1: Mechanism of dyeing nylon acid dyes

A similar mechanism for wool dyeing with acid dyes (Figure 2) reveals that dye attachment onto wool is by ionic or salt links. 


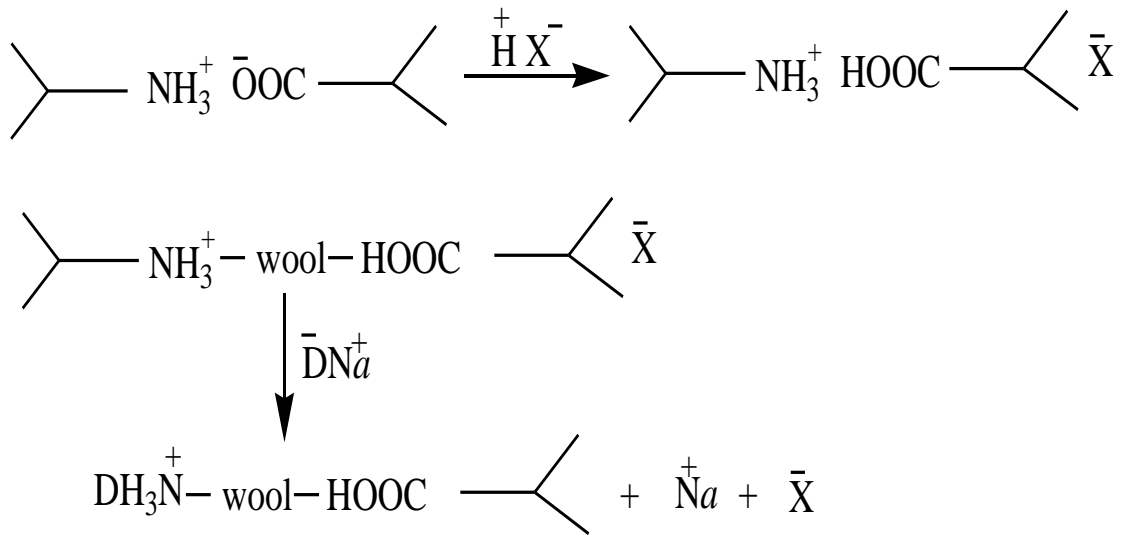

Figure 2: Mechanism of dyeing wool acid dyes

\subsection{Fastness Properties of the dyed Nylon and Wool fabrics}

At the end of the soaping process, the dyed materials were found to be brighter when compared to their appearance before soaping.

The results of these fastness tests are shown in Table 7, 8, 9, 10 and 11. Tables 5 and 6 describe the normal fastness grades (washing, pressing, bleaching, perspiration etc) and light fastness grades respectively [13]

Table 5. Description of normal fastness grades

\begin{tabular}{llll}
\hline $\begin{array}{l}\text { Fastness } \\
\text { grade }\end{array}$ & $\begin{array}{l}\text { Shade change of } \\
\text { tested sample }\end{array}$ & Fastness & $\begin{array}{c}\text { Staining of adjacent } \\
\text { white sample }\end{array}$ \\
\hline Grade 5 & No change & Excellent & No staining \\
Grade 4 & Slight loss in depth & Good & Very slight staining \\
Grade 3 & Appreciable loss & Fair & Moderate staining \\
Grade 2 & Significant loss & Poor & Significant staining \\
Grade 1 & Great loss in depth & Very poor & Deep staining \\
\hline
\end{tabular}

Table 6. Description of the light fastness grades

\begin{tabular}{lll}
\hline $\begin{array}{l}\text { Fastness } \\
\text { Grade }\end{array}$ & $\begin{array}{l}\text { Degree of } \\
\text { fading }\end{array}$ & $\begin{array}{l}\text { Light } \\
\text { fastness }\end{array}$ \\
\hline Grade 8 & None & Outstanding \\
Grade 7 & Very, very slight & Excellent \\
Grade 6 & Slight & Very good \\
Grade 5 & Moderate & Good \\
Grade 4 & Appreciable & Moderate \\
Grade 3 & Significant & Fair \\
Grade 2 & Extensive & Poor \\
Grade 1 & Very extensive & Very poor \\
\hline
\end{tabular}

Table 7: Fastness rating for the degree of staining of adjacent white material by dyed wool fabric.

\begin{tabular}{|c|c|c|c|c|c|c|c|}
\hline & \multirow{2}{*}{$\begin{array}{c}\text { Fastness to } \\
\text { bleaching }\end{array}$} & \multirow{2}{*}{$\begin{array}{c}\text { Fastness to } \\
\text { washing }\end{array}$} & \multirow{2}{*}{ Rubbring } & \multicolumn{2}{|c|}{ Fastness pressing } & \multicolumn{2}{|c|}{ Perspiration } \\
\cline { 5 - 8 } & & & Dry & Damp & Alkaline & Acidic \\
\hline A & $4-5$ & 3 & 4 & 4 & 4 & 4 & 4 \\
\hline B & 3 & $3-4$ & 3 & 4 & 3 & 4 & 3 \\
\hline C & $3-4$ & 3 & 4 & 4 & 3 & 3 & 3 \\
\hline D & $3-4$ & $3-4$ & 4 & 5 & 4 & 4 & 4 \\
\hline
\end{tabular}


Table 8: Colour fastness rating for the wool fabrics

\begin{tabular}{|c|c|c|c|c|c|c|c|}
\hline \multirow[t]{2}{*}{ Dye } & \multirow[t]{2}{*}{$\begin{array}{l}\text { Fastness to } \\
\text { bleaching }\end{array}$} & \multirow[t]{2}{*}{$\begin{array}{l}\text { Fastness to } \\
\text { washing }\end{array}$} & \multirow[t]{2}{*}{$\begin{array}{l}\text { Fastness to } \\
\text { Rubbing }\end{array}$} & \multicolumn{2}{|c|}{$\begin{array}{l}\text { Fastness to } \\
\text { pressing }\end{array}$} & \multicolumn{2}{|c|}{$\begin{array}{l}\text { Fastness to } \\
\text { Perspiration }\end{array}$} \\
\hline & & & & Dry & Damp & $\begin{array}{l}\text { Alkalin } \\
\text { e }\end{array}$ & Acid \\
\hline $\mathrm{A}$ & 5 & 2 & 4 & 5 & 4 & 4 & 4 \\
\hline B & 4 & 1 & 4 & 5 & 3 & 4 & 3 \\
\hline $\mathrm{C}$ & 4 & 2 & 4 & 5 & 3 & 3 & 3 \\
\hline $\mathrm{D}$ & 4 & 2 & 4 & 5 & 4 & 4 & 4 \\
\hline
\end{tabular}

Table 9: Fastness rating for the degree of staining of adjacent white fabric by dyed nylon fabric

\begin{tabular}{|c|c|c|c|c|c|c|c|}
\hline \multirow[t]{2}{*}{ Dye } & \multirow[t]{2}{*}{$\begin{array}{l}\text { Fastness to } \\
\text { bleaching }\end{array}$} & \multirow[t]{2}{*}{$\begin{array}{l}\text { Fastness to } \\
\text { washing }\end{array}$} & \multirow[t]{2}{*}{$\begin{array}{l}\text { Fastness to } \\
\text { Rubbing }\end{array}$} & \multicolumn{2}{|c|}{$\begin{array}{c}\text { Fastness to } \\
\text { pressing }\end{array}$} & \multicolumn{2}{|c|}{$\begin{array}{ll}\text { Fastness } & \text { to } \\
\text { Perspiration } & \end{array}$} \\
\hline & & & & Dry & Damp & Alkaline & Acidic \\
\hline $\mathrm{A}$ & $4-5$ & 3 & 4 & 4 & 4 & 4 & 3 \\
\hline B & 3 & $2-3$ & 4 & 4 & 3 & 3 & 3 \\
\hline $\mathrm{C}$ & $4-5$ & $4-5$ & 4 & 5 & 3 & 3 & 4 \\
\hline $\mathrm{D}$ & $4-5$ & 4 & $3-4$ & 5 & 4 & 4 & $4-5$ \\
\hline
\end{tabular}

Table 10: Colour change of dyed nylon fabric after washing, bleaching, rubbing and pressing.

\begin{tabular}{|c|c|c|c|c|c|c|c|}
\hline \multirow{2}{*}{ Dye } & \multirow{2}{*}{$\begin{array}{l}\text { Fastness to } \\
\text { bleaching }\end{array}$} & $\begin{array}{l}\text { Fastness to } \\
\text { washing }\end{array}$ & \multirow{2}{*}{$\begin{array}{l}\text { Fastness to } \\
\text { Rubbing }\end{array}$} & \multicolumn{2}{|l|}{$\begin{array}{l}\text { Fastness to } \\
\text { pressing }\end{array}$} & \multicolumn{2}{|c|}{$\begin{array}{c}\text { Fastness to } \\
\text { Perspiration }\end{array}$} \\
\cline { 5 - 9 } & & & Dry & Damp & Alkaline & Acidic \\
\hline A & 4 & 1 & 4 & 5 & 4 & 4 & 4 \\
\hline B & 4 & 2 & 4 & 5 & 4 & 3 & 4 \\
\hline C & 4 & 1 & 5 & 5 & 5 & 3 & 5 \\
\hline D & 5 & 1 & 5 & 5 & 5 & 4 & 5 \\
\hline
\end{tabular}

Table 11: Light fastness rating of dyed wool and nylon fabrics.

\begin{tabular}{|c|c|c|}
\hline \multirow{2}{*}{ Dye } & Wool & Rylon \\
\cline { 2 - 3 } & 5 & 4 \\
\hline A & 3 & 3 \\
\hline B & 7 & 3 \\
\hline C & 7 & 4 \\
\hline
\end{tabular}

It is evident from the result of the assessments presented on Table $7-11$ that the nylon and wool fabric exhibited good to excellent fastness test to bleaching, rubbing, pressing and perspiration but poor fastness to light and washing.

However, the good fastness to rubbing obtained indicates that there was no staining of other fabric rubbed against the dyed fabric. Also the test for dry and damp fastness to pressing showed excellent and good ratings respectively, thus both dry and damp pressing are recommended for nylon and wool fabrics when dyed with acid dyes. Another positive results obtained were good fastness to bleaching and this implies that bleaching agents do not have adverse effects on the dyed fabrics.

\section{Conclusion and Recommendation.}

From the results of the study it may be observed that acid dyes have good substantively and high exhaustion for both nylon and wool fabrics, even though nylon has higher percentage exhaustion, which may be due to its open structure. Nylon however is less thick fabric than wool. Both nylon and wool fabrics showed good colour fastness properties to bleaching agents, pressing (dry and damp) and perspiration but poor fastness to high and washing.

However, it may be concluded that dye B may be more suitable for dyeing nylon and wool be more suitable for dyeing nylon and wool fabrics based on the results obtained and can be utilize by both local and commercial dyers. The draw backs found (poor light and wash fastness) may be overcome by suitable after treatments hence research efforts should be tilted towards enhancement of the properties of acid dyed wool and nylon fabrics through after treatments. 


\section{References}

[1] P.O. Nkeonye, Fundamental Principles of Textile Dyeing, (Printing and Finishing A. B. U. Press L.t.d. 1987), 135 - 145

[2] R.W. David and H.Geoffrey . The Chemistry and Application of Dyes (Plenum Press Newyork and London, 1990$)$ pp203 - 235.

[3] L. J. Marjory, Introductory Textile Sciences, $3^{\text {rd }}$ Edition library of Congress Cataloging in Publication of Data U. S. A. 1977, 88 115 .

[4] C. L. Bird and W. S. Boston . Theory of Colouration of Textiles. (White Rose Press L.t.d., Mexborough and London, 1975 ), pp285.

[5] M. D. Koushic Uddin and H. M. Sonia. A comparative study on silk Dyeing with Acid and Reactive Dye. Int. J. Engr. and Tech. 2010, 10(6):21-26.

[6] H. Ghouila, N. Meksi, W. Haddar, M.F. Mhenni, H.B. Jannet, Identification and dyeing studies of Isosali purposide, natural chalcone dye from acacia cynophyilla followers on wool. Industrial crops products, 35, 31-36. 2012.

[7] L. J. Majory. Essentials of Textiles, $2^{\text {nd }}$ Edition, Holt, (Rinehart Winston Publishers, U.S.A. 1980), 55 - 102.

(8] E. R. Trotman. Dyeing and Chemical Technology of Fibres. London and (Highway Coube, Charles Griffin and Company L.t.d. 1975),9.

[9] A.Guesmi, N. B. Hamadi, N. Ladhari, F.. Sakli, Dyeing Properties and colour fastness of wool dyed with indicaxanthin natural dye. Industrial crops and products 37, 493-499, 2012.

[10] A.Guesmi, N. B. Hamadi, N. Ladhari, F.. Sakli, Sonicator dyeing of modified acrylic fabric with indin caxanthin natural dye. Industrial crop and Products, 42, 63-69 (2013).

[11] M. Feiz, S. Mallakpour, M.A. Azizollah, M.A. Aftertreatment of direct dyes on wool and nylon 6 with syntans and a syntans/ cationic system. Dyes and pigments, 74, 258-261.

[12] P. O. Nkeonye, Introductory Textiles for Home Economists Students, (Asekome and Co. Publishers Samaru Zaria, Nigeria, 1993, 51.

[13] A. D. Broadbent, Basic Principles of Textile Colouration (Society of Dyers and Colourists, England, $2001,535$. 